\title{
Evaluation of Kenaf (Hibiscus cannabinus) genotypes suitable for Paper Industry
}

\author{
R. Pushpa*, M. Raju and Subyasachi Mitra
}

Tamil Nadu Rice Research Institute, Aduthurai, India

*Corresponding author

K e y w o r d s
Paper pulp,
Fiber yield,
germplasm,
Kenaf
Hibiscus
cannabinus
Article Info
Accepted:
28 February 2020
Available Online:
10 March 2020

Keywords

Paper pulp,

Fiber yield,

cannabinus

Article Info

Accepted:

Available Online

10 March 2020

\section{A B S T R A C T}

Kenaf is 3-5 times more productive per unit area than pulpwood trees producing pulp with quality equal to or superior to that of many woody species. In this study 77 Hibiscus cannabinus germplasm including two checks was evaluate to identify the genotype suitable for paper pulp. The experimental materials were grown in a randomized block design with three replications at the Tamil Nadu Rice Research Institute, Aduthurai for All India Jute \& Allied Fibres during 2016. The analysis of variance revealed significant difference among the genotypes for all the three characters. A narrow range of difference between phenotypic coefficient of variation PCV and genotypic coefficient of variation. GCV has recorded for Plant height (9.78 to 7.11), Basal Diameter (22.41 to 19.66) and fibre yield (26.70 to 25.14) indicating less environmental influence on the phenotypic experiment of these characters and they are mostly governed by genetic factors. Hence selection of derived character simply on the phenotypic value may be effective. High $\mathrm{h}^{2}$ with high GA for basal diameter and fibre yield indicating the predominance of additive gene effects on such traits. This study indicates that basal diameter and fibre yield with high GA should be taken in consideration during selection of higher yield.

\section{Introduction}

Hibiscus cannabinus is largely cultivated for its fibre which is extensively employed by the natives in the manufacture of rope, coarse sacking and other articles required for agricultural purposes. It has long been used in trade of cordage products in making twines, ropes, sacs, and fishing nets. World production of Kenaf fibres is estimated at 400000 tons per year, Whereas India being the largest producer. Kenaf is used as a part of interior material of car such as head liners and automobile dash boards. It would be a natural substitute for fibre glass in future. It serves as material for carpet padding and corrugated medium and fire resistant differential density. It is also used in synthetic fibres molded plastics. PLA-based (Polylactic acid) materials are a new class of materials that in recent years have aroused an ever growing interest due to the continuously increasing environmental awareness throughout the world. 
Kenaf plants rapidly produce a tremendous amount of biomass, meaning that it has a great potentiality as an alternative source of raw material for making paper. In assessing kenaf as an alternative raw material for pulping, it shows a promising prospect. It makes a bright, high-quality paper that resist yellowing (Banuelos, 2000). Kenaf is attracting a considerable interest of the paper industry as a source of good quality cellulose fibres. Being an annual herbaceous plant, it is fast growing and high yielding and pulp is easily obtained. Kenaf can be used as an alternative raw material for pulp due to its excellent advantages of being renewable, inexpensive and growing ability under severe conditions such as low water supply and little fertilizer. Kenaf is 3-5 times more productive per unit area than pulpwood trees producing pulp with quality equal to or superior to that of many woody species. Several studies have identified Kenaf to be an interesting substitute for woody species utilized for paper pulp production have tried to improve the surface property of hand sheets prepared from the Kenaf material, and noticed that a biopolymer of chitosan has ability to form films that improve the surface properties of paper when it is applied to the surface of the sheet and for preparation of net to trap the animals. India is using mesta for paper pulp. The cultivation of mesta crop for paper pulp is done almost in the same manner as it is done for fibre purpose. However, the main emphasis is given on the thick and tall plants. The thick plants produce more pulp. In this study kenaf germplasm is evaluate to identify the genotype suitable for paper pulp.

\section{Materials and Methods}

The material for the present study comprised of 77 Hibiscus cannabinus genotypes including two check varieties. The experimental materials were grown in a randomized block design with three replications at the Tamil Nadu Rice Research Institute, Aduthurai for All India Jute \&Allied Fibres during 2016. Row to row and plant to plant distances were $40 \mathrm{~cm}$ and $7 \mathrm{~cm}$, respectively. Standard package of practices were followed to raise the crop. Net plots were harvested at 120 days after sowing. Data were recorded for three characters viz. plant height, Basal diameter $(\mathrm{mm})$, fibre yield. Plant height was recorded as total plant height from base to top including all flowering nodes at harvesting stage. The stem diameter was measured at mid point between base to top at harvesting stage. Fibre yield was observed after harvesting, retting and drying of fibre. Observations were recorded on 10 randomly selected plants in each of three replications at specified stages of crop growth period when the characters under study had full expression.

\section{Results and Discussion}

The analysis of variance revealed significant difference among the genotypes for all the three characters studied (Table 1) suggesting presence of wide variability in the studied germplasm which was also depicted by the range values of all the three traits (Table 2). The plant height ranged from 211.25to $311.25 \mathrm{~cm}$; Average basal diameter of the accessions ranged from 0.93 to $2.28 \mathrm{~cm}$ and fibre yield per plant ranged from 4.6 to 14.75 g. These concurrent results have depicted that large amount of variability are present in the germplasm under study.

\section{Genetic Variability Analysis}

In general, phenotypic variances were higher than the corresponding genotypic variances for all the characters under study (Table 3). The phenotypic variance was the highest for plant height (9.78) followed by total biomass (41.72) and leaf yield (12.85).

A narrow range of difference between 
phenotypic coefficient of variation PCV and genotypic coefficient of variation GCV has recorded for Plant height(9.78 to 7.11), Basal Diameter (22.41 to 19.66) and fibre yield (26.70 to 25.14) indicating less environmental influence on the phenotypic experiment of these characters and they are mostly governed by genetic factors. Hence selection of derived character simply on the phenotypic value may be effective.

Further, the estimates of PCV were generally higher than their corresponding GCV for plant height and basal diameter suggesting thereby the important role of environment in the expression of these traits. Hence, phenotypic selection may not hold good for genetic improvement in these traits. These findings are in agreement with Dastidar et al., (1993), Islam et al., (2002), Palve et al., (2003), Echekwu and Showemino (2004), Ibrahim and Hussein (2006), Ghodke and
Wadikar (2011); Nwangburuka et al., (2012) and Ibrahim et al., (2013).

High $\mathrm{h}^{2}$ with high GA for basal diameter and fibre yield indicating the predominance of additive gene effects on such traits. This study indicates that basal diameter and fibre yield with high GA should be taken in consideration during selection of higher yield. These findings were correlated with the results of Nwangburuka et al., (2012) and Ibrahim et al., (2013). High heritability coupled with high genetic advance as percent of mean for plant height, pods plant-1 and seed yield plant-1 indicates the operation of additive genes and offer the best possibility for improvement of this trait through mass selection, progeny selection, family selection to any other suitable modified selection procedure aiming to exploit the additive gene effects (Bhakuni Vandana et al., 2017).

Table.1 Analysis of variance for three characters in kenaf (Hibiscus cannabinus) germplasm

\begin{tabular}{|l|c|c|c|c|}
\hline $\begin{array}{l}\text { Source of } \\
\text { variation }\end{array}$ & df & $\begin{array}{c}\text { Plant height } \\
(\mathbf{c m})\end{array}$ & $\begin{array}{c}\text { Basal diameter } \\
(\mathbf{m m})\end{array}$ & $\begin{array}{c}\text { Fibre yield } \\
\text { (g/plot) }\end{array}$ \\
\hline Replication & 1 & 1131.858 & 0.264 & 3.897 \\
\hline Genotype & 76 & $1076.881^{* *}$ & $0.193^{* *}$ & $9.848^{* *}$ \\
\hline Error & 76 & 331.842 & 0.025 & 0.590 \\
\hline
\end{tabular}

Table.2 Mean performance of kenaf (Hibiscus cannabinus) germplasm

\begin{tabular}{|l|l|c|c|c|}
\hline Sl.no & Accession no. & $\begin{array}{c}\text { Plant height } \\
(\mathbf{c m})\end{array}$ & $\begin{array}{c}\text { Basal Diameter } \\
(\mathbf{c m})\end{array}$ & $\begin{array}{c}\text { Fibre weight } \\
\text { g/plt }\end{array}$ \\
\hline $\mathbf{1}$ & KIN-036 & 275.00 & 2.05 & 14.75 \\
\hline $\mathbf{2}$ & KIN-037 & 288.75 & 1.95 & 13.65 \\
\hline $\mathbf{3}$ & KIN-038 & 275.00 & 1.64 & 9.00 \\
\hline $\mathbf{4}$ & KIN-039 & 273.75 & 1.61 & 9.25 \\
\hline $\mathbf{5}$ & KIN-040 & 278.75 & 1.36 & 6.75 \\
\hline $\mathbf{6}$ & KIN-041 & 281.25 & 1.86 & 8.25 \\
\hline $\mathbf{7}$ & KIN-042 & 265.00 & 1.64 & 8.05 \\
\hline $\mathbf{8}$ & KIN-043 & 298.75 & 1.56 & 8.55 \\
\hline $\mathbf{9}$ & KIN-044 & 291.25 & 0.93 & 6.45 \\
\hline
\end{tabular}


Int.J.Curr.Microbiol.App.Sci (2020) 9(3): 3258-3263

\begin{tabular}{|c|c|c|c|c|}
\hline 10 & KIN-045 & 278.75 & 0.98 & 6.00 \\
\hline 11 & KIN-046 & 290.00 & 1.00 & 6.70 \\
\hline 12 & KIN-047 & 311.25 & 1.16 & 6.75 \\
\hline 13 & KIN-048 & 296.25 & 0.96 & 6.45 \\
\hline 14 & KIN-049 & 283.75 & 1.05 & 9.75 \\
\hline 15 & KIN-050 & 294.25 & 1.57 & 12.65 \\
\hline 16 & KIN-052 & 263.75 & 1.05 & 10.80 \\
\hline 17 & KIN-056 & 248.75 & 0.98 & 12.10 \\
\hline 18 & $\mathrm{KIN}-058$ & 285.00 & 1.39 & 9.75 \\
\hline 19 & KIN-060 & 277.50 & 0.94 & 10.55 \\
\hline 20 & KIN-061 & 287.50 & 1.55 & 13.70 \\
\hline 21 & KIN-064 & 273.75 & 1.25 & 9.55 \\
\hline 22 & KIN-065 & 298.75 & 0.99 & 7.25 \\
\hline 23 & KIN-066 & 287.50 & 1.08 & 13.35 \\
\hline 24 & KIN-067 & 303.75 & 1.34 & 7.10 \\
\hline 25 & KIN-068 & 238.75 & 1.25 & 8.70 \\
\hline 26 & KIN-069 & 273.75 & 1.15 & 9.65 \\
\hline 27 & KIN-070 & 247.50 & 1.20 & 6.60 \\
\hline 28 & KIN-072 & 302.50 & 1.32 & 6.70 \\
\hline 29 & KIN-073 & 276.25 & 1.46 & 7.75 \\
\hline 30 & KIN-075 & 285.00 & 1.15 & 7.40 \\
\hline 31 & KIN-076 & 261.25 & 1.10 & 8.90 \\
\hline 32 & KIN-077 & 280.00 & 1.16 & 10.85 \\
\hline 33 & KIN-079 & 217.50 & 1.00 & 7.05 \\
\hline 34 & KIN-080 & 230.25 & 1.15 & 6.95 \\
\hline 35 & KIN-081 & 283.75 & 1.69 & 9.65 \\
\hline 36 & KIN-082 & 291.25 & 1.49 & 9.45 \\
\hline 37 & KIN-083 & 280.00 & 1.57 & 11.95 \\
\hline 38 & KIN-084 & 248.00 & 1.63 & 7.20 \\
\hline 39 & KIN-085 & 246.75 & 1.60 & 8.35 \\
\hline 40 & KIN-086 & 242.50 & 1.68 & 7.65 \\
\hline 41 & KIN-089 & 231.25 & 1.38 & 7.20 \\
\hline 42 & KIN-091 & 261.25 & 1.39 & 8.40 \\
\hline 43 & KIN-095 & 257.50 & 1.23 & 7.05 \\
\hline 44 & KIN-099 & 221.25 & 1.40 & 7.70 \\
\hline 45 & KIN-123 & 285.00 & 1.50 & 5.25 \\
\hline 46 & KIN-124 & 266.25 & 1.59 & 8.25 \\
\hline 47 & KIN-125 & 275.00 & 1.35 & 8.05 \\
\hline 48 & KIN-146 & 288.75 & 1.68 & 8.65 \\
\hline 49 & KIN-127 & 264.25 & 1.49 & 9.20 \\
\hline
\end{tabular}




\begin{tabular}{|c|c|c|c|c|}
\hline 50 & KIN-141 & 304.00 & 1.92 & 6.70 \\
\hline 51 & KIN-143 & 264.75 & 1.71 & 9.05 \\
\hline 52 & KIN-144 & 253.75 & 1.68 & 9.15 \\
\hline 53 & KIN-145 & 283.75 & 1.60 & 6.70 \\
\hline 54 & KIN-146 & 238.25 & 1.68 & 7.00 \\
\hline 55 & KIN-147 & 211.25 & 1.86 & 12.70 \\
\hline 56 & KIN-148 & 246.50 & 1.78 & 5.30 \\
\hline 57 & KIN-149 & 217.50 & 1.80 & 6.60 \\
\hline 58 & KIN-151 & 267.50 & 1.79 & 7.55 \\
\hline 59 & KIN-154 & 237.50 & 1.50 & 5.20 \\
\hline 60 & KIN-156 & 271.25 & 1.38 & 7.60 \\
\hline 61 & KIN-158 & 265.00 & 1.46 & 9.10 \\
\hline 62 & KIN-168 & 240.50 & 1.38 & 10.60 \\
\hline 63 & KIN-159 & 257.50 & 1.51 & 10.05 \\
\hline 64 & KIN-170 & 257.50 & 1.76 & 7.60 \\
\hline 65 & KIN-171 & 283.75 & 2.01 & 7.25 \\
\hline 65 & KIN-175 & 249.75 & 1.32 & 6.80 \\
\hline 67 & KIN-176 & 265.25 & 1.80 & 9.75 \\
\hline 68 & KIN-177 & 285.00 & 1.47 & 5.70 \\
\hline 69 & KIN-178 & 296.25 & 1.96 & 7.10 \\
\hline 70 & KIN-179 & 268.75 & 1.67 & 6.10 \\
\hline 71 & KIN-207 & 284.00 & 1.68 & 9.15 \\
\hline 72 & KIN-214 & 296.25 & 1.50 & 7.40 \\
\hline 73 & KIN-220 & 303.75 & 2.05 & 7.60 \\
\hline 74 & KIN-221 & 292.50 & 1.43 & 9.10 \\
\hline 75 & KIN-231 & 277.50 & 1.31 & 4.60 \\
\hline 76 & HC 583+ & 297.50 & 1.90 & 11.55 \\
\hline \multirow[t]{7}{*}{77} & AMC 108+ & 300.50 & 2.28 & 13.15 \\
\hline & Mean & 271.18 & 1.47 & 8.54 \\
\hline & C.V. & 6.72 & 10.76 & 9.00 \\
\hline & F ratio & 3.25 & 7.68 & 16.62 \\
\hline & F Prob. & 0.00 & 0.00 & 0.00 \\
\hline & S.E. & 12.88 & 0.11 & 0.54 \\
\hline & C.D. $5 \%$ & 36.28 & 0.32 & 1.53 \\
\hline
\end{tabular}

Table.3 Genetic variability parameters in roselle (Hibiscus cannabinus L.) for seed yield and its contributing characters

\begin{tabular}{|l|c|c|c|c|c|c|c|}
\hline \multicolumn{1}{|c|}{ Character } & Mean & Range & GCV (\%) & PCV (\%) & h(\%) & GA & GAM \\
\hline Plant height $(\mathbf{c m})$ & 271.17 & $211.25-311.25$ & 7.11 & 9.78 & 52.9 & 10.66 & 13.66 \\
\hline Basal diameter (mm) & 1.474 & $0.93-2.28$ & 19.66 & 22.41 & 77.0 & 35.54 & 45.54 \\
\hline Fiber yiels (g/plot) & 8.543 & $4.6-14.75$ & 25.14 & 26.70 & 88.6 & 45.54 & 62.49 \\
\hline
\end{tabular}

PCV=Phenotypic Coefficient of Variation, GCV= Genotypic Coefficient of Variation, GA= Genetic advance and $\mathrm{GAM}=$ Genetic advance as per cent mean 
In conclusion, the analysis of variance showed significant differences among seventy seven germplasm of Kenaf for all characters studied indicating wider variability and high diversity among genotypes. The genotypic coefficient of variation for all characters studied was higher than the phenotypic coefficient of variation indicating less environmental influence on the phenotypic experiment of these characters and they are mostly governed by genetic factors. High $\mathrm{h}^{2}$ with high GA for basal diameter and fibre yield indicating the predominance of additive gene effects on such traits indicates the operation of additive gene action in the inheritance of these traits and improvement in these characters is possible through simple selection

\section{References}

Banuelos, G.S., 2000. Kenaf and canolaSelenium slurpers. Agril. Res, June, pp10-11.

Bhakuni Vandana, Shukla, P.S., Singh Kamendra and Vikash Kumar Singh. 2017. Morphological Characterization and Assessment of Genetic Variability in Soybean Varieties. Int. J. Curr. Microbiol. App. Sci., 6(3): 361-369

Dastidar, K.K.G., Agarwalla, K.K. and Roychowdhury P. 1993. Genetic variability and association component characters for seed yield in Olitorius jute. Indian J. Genet., 53(2): 157-160.
2004. Genetic, Phenotypic and environmental variances and character association in kenaf. African Crop Sci. J., 12(4): 321326.

Ghodke, M.K. and Wadikar, P.B. 2011. Estimates of genetic variation and heritability for yield and its attributes in kenaf (Hibiscus cannabinus L.). Res. J. Agric. Sci., 2(3): 737-739.

Islam, M.R., Islam, M.M., Akter, N. and Ghosh, R.K. 2002. Genetic variability and performance of tossa jute (Corchorus oiltorius L.). Pak. J Biol. Sci., 5(7): 744-745.

Ibrahim, M.M. and Hussein, R.M. 2006. Variability, heritability and genetic advance in some genotypes of roselle (Hibiscus sabdariffa L.). World J. Agric. Sci., 2(3): 340-345.

Ibrahim, E.B., Abdalla, A.W.H., Ibrahim, E.A. and Naim, A.M.E. 2013. Variability in some roselle (Hibiscus sabdariffa L.) genotypes for yield and its attributes. Int. J Agric. Forestry, 3(7): 261-266.

Nwangburuka, C.C., Denton, O.A., Kehinde, O.B., Ojo, D.K. and Popoola, A.R. 2012. Genetic variability and heritability in cultivated okra [Abelmoschus esculentus (L.) Moench]. Spanish J. Agric. Res., 10(1): 123-129.

Palve, S.M., Kumar, D., Chaudhury, S.K. and Gupta, D. 2003. Genetic variation for seed yield in jute (Corchorus spp.). Indian J. Genet., 63(3): 235238.

Echekwu, C.A. and Showemimo, F.A.

\section{How to cite this article:}

Pushpa, R., M. Raju and Subyasachi Mitra. 2020. Evaluation of Kenaf (Hibiscus cannabinus) genotypes suitable for Paper Industry. Int.J.Curr.Microbiol.App.Sci. 9(03): 3258-3263. doi: https://doi.org/10.20546/ijcmas.2020.903.373 